hand rub and use disposable plastic aprons or gowns before and after contact with an affected patient or his immediate environment. Patients should use an antiseptic detergent for washing and bathing.

The working party favours a dedicated unit for isolating patients with epidemic resistant $S$ aureus. Failing that, it preferred a small ward with designated staff to side wards or rooms in general wards, where staff do not understand or have time for infection control. This recommendation is supported by the experience from several outbreaks ${ }^{11}{ }^{12}{ }^{31} 32$; and in one hospital spread increased when a unit was closed and reduced again when it was reopened. The cost of such a unit must be weighed against the lengthened hospital stay of more cases without one.

Treatment to eliminate $S$ aureus from carriers and cases is unreliable at best, and epidemic resistant $S$ aureus responds poorly to nasal antiseptics. ${ }^{32}$

The guidelines suggest mupirocin for nasal carriage ${ }^{12}{ }^{33}$ and to treat the organism in eczema and pressure sores. Clearance may be declared only after three weekly negative swabs from the nose, axillae, fingers, perineum, and lesions. Clearly, the doctor in charge of a patient should on discharge tell the general practitioner or the infection control officer of the receiving hospital.

Consultant Microbiologist,

P J SANDERSON

Edgware General Hospital,

Edgware,

Middlesex HA8 0AD

1 Combined working party of the Hospital Infection Society and British Society for Antimicrobial Chemotherapy. Guidelines for the control of epidemic methicillin resistant Staphylococcus Chemotherapy. Guidelines for the cont

2 Marples RR, Richardson JF, de Saxe MJ. Bacteriological characters of strains of Staphylococcus aureus submitted to a reference laboratory related to methicillin resistance. f Hyg (Camb) 1986;96:217-23.

3 Jevons MP. "Celbenin" resistant staphylococci. Br Med $\mathcal{f} 1961$;i:124-5.

4 Anonymous. Methicillin resistant staphylococci. [Editorial]. Lancet 1968;ii:759.

5 Ayliffe GAJ, Lilly HA, Lowbury EJL. Decline of the hospital staphylococcus? Incidence of multiresistant Staphylococcus aureus in three Birmingham hospitals. Lancet 1979;i:538-41.

6 Shanson DC, Kensit JG, Duke R. Outbreak of hospital infection with a strain of Staphylococcus aureus resistant to gentamicin and methicillin. Lancet 1976;ii:1347-8.

7 Pavillard R, Harvey K, Douglas D, et al. Epidemic of hospital-acquired infection due to methicillin-resistant Staphylococcus aureus in major Victorian hospitals. Med $\mathcal{F}$ Aust 1982; 451-4.

8 McDonald M, Hurse A, Sim KN. Methicillin-resistant Staphylococcus aureus in bacteraemia. Med F A ust 1981;ii:191-4.

9 Med $\mathrm{f}$ Aust $1981 ; \mathrm{in}: 191.4$. Hone R, Cafferkey M, Keane CT, et al. Bacteraemia
Staphylococcus aureus. $\mathcal{F}$ Hosp Infect 1981;2:119-26.

10 Braph JM, Noouse a London hospital. Lancet 1985 ;i:1493-5.

11 Shanson DC, Johnstone D, Midgley J. Control of a hospital outbreak of methicillin-resistant Staphylococcus aureus infection: value of an isolation unit. $\mathcal{F}$ Hosp Infect 1985;6:285-92.

12 Dacre J, Emmerson A, Jenner EA. Gentamicin-methicillin-resistant Staphylococcus aureus: epidemiology and containment of an outbreak. I Hosp Infect 1986;7:130-6.

13 Boyce JM, Causey WA. Increasing occurrence of methicillin-resistant Staphylococcus aureus in the United States. Infection control 1982;3:377-83.

14 Lacey RW, Chopra I. The effect of plasmid carriage on the virulence of Staphylococcus aureas. $f$ Med Microbiol 1975;8:137-47.

15 Thompson RL, Cabezudo I, Wensel RP. Epidemiology of nosocomial infection caused by methicillin-resistant Staphylococcus aureus. Ann Intern Med 1982;97:309-17.

16 Crossley K, Landesman B, Zaske D. An outbreak of infections caused by strains of Staphylococcus aureus resistant to methicillin and aminoglycosides. $\mathcal{F}$ Infect Dis 1979;139. 280-7.

17 Boyce JM, Landry M, Deetz TR, DuPont HL. Epidemiologic studies of an outbreak of nosocomial methicillin-resistant Staphylococcus aureas infections. Infection Control 1981;2: nosocom.

18 Peacock JE Jr, Moorman DR, Wenzel RP, Mandell GL. Methicillin-resistant Staphylococcus aureus: microbiological characteristics, antimicrobial susceptibilities and assessment of virulence of an epidemic strain. $\mathcal{F}$ Infect Dis 1981;144:575-82.

19 Lacey RW, Barr KW, Barr VE, Inglis TJ. Properties of methicillin resistant Staphylococcus aureus colonising patients in a burns unit. $\mathcal{F}$ Hosp Infect 1986;7:137-48

20 Williams REO. Skin and nose carriage of bacteriophage types of Staphylococcus aureus. Fournal of Pathology and Bacteriology 1946;48:259-70.

21 Fitzpatrick DJ, Cafferkey MT, Toner M, Beattie T, Keane CT. Osteomyelitis with methicillin resistant Staphylococcus aureus. $\mathcal{F}$ Hosp Infect 1986;1:24-30

22 Price EH, Brain A, Dickson JAS. An outbreak of infection with a gentamicin and methicillinresistant Staphylococcus aureus in a neonatal unit. $\mathcal{F}$ Hosp Infect 1980:1:221-8.

23 Saroglou G, Cromer M, Bisno AL. Methicillin-resistant Staphylococcus aureus: interstate spread of nosocomial infections with emergence of gentamicin-methicillin resistant strains. Infection control 1980;1:81-9.

24 Townsend DE, Ashdown N, Annear DI, Pearman JW, Grubb WB. Genetic analysis of methicillin-resistant Staphylococcus aureus from a Western Australian hospital. $\mathcal{f}$ Hosp Infect 1984;5:417-24.

25 Shanson DC, McSwiggan DA. Operating theatre acquired infection with a gentamicin-resistant strain of Staphyloccus aureus: outbreaks in two hospitals attributable to one surgeon. $\mathcal{f}$ Hosp Infect 1980;1:171-2.
26 Cookson BD, Farrington M, Webster M, Phillips I. Methicillin resistant Staphylococcus aureus. Lancet 1985;ii:218-9.

27 Hare R, Ridley M. Further studies in the transmission of Staphylococcus aureus. Br Med $\mathcal{J}$ 1958;i:69-76.

28 Shooter RA, Smith MA, Griffiths JD, et al. Spread of staphylococci in a surgical ward. Br Med $\mathcal{F}$ 1958;i:607-13.

29 King K, Brady L, Thomson M, Harkness JL. Antibiotic-resistant staphylococci in a teaching hospital. Med f Aust 1982;ii:461-5.

30 Lidwell OM, Lowbury EJ. The survival of bacteria in dust. I. The distribution of bacteria in floor dust. $\mathcal{F}$ Hyg (Lond) 1950;48:6-12.

31 Selkon JB, Stokes ER, Ingham HR. The role of an isolation unit in the control of hospital infection with methicillin-resistant staphylococci. I Hosp Infect 1980;1:41-6.

32 Pearman JW, Christiansen KJ, Annear DI, et al. Control of methicillin-resistant Staphylococcus aureus (MSRA) in an Australian metropolitan teaching hospital complex. Med $\mathcal{J}$ Aust aureus (MSRA)
$1985 ; 142: 103-8$.

33 Casewell MR, Hill RLR. Elimination of nasal carriage of Staphylococcus aureus with mupirocin ('pseudominic acid')—a controlled trial. I Antimicrob Chemother 1986;17:365-72.

\section{Murdering while asleep}

A person who commits a criminal act while asleep is not conscious of his actions and cannot be held legally responsible for them. The law calls these acts sane automatisms, and Lord Justice Lawton has described them as a "quagmire of the law, seldom entered save by those in desperate need of some kind of a defence." Recently defence counsels have shown less reluctance to enter this quagmire. It is therefore essential that the court examines critically any medical evidence presented in such cases.

Is it possible for people to act violently, and even kill, during sleep? Yes-but only exceptionally..$^{2.5}$ A night's sleep consists of cycles of slow wave sleep and rapid eye movement (REM or dreaming) sleep, alternating in periods of about 90 minutes. What we think of as dreaming, with complex imagery and a narrative, occurs in REM sleep. Dreams and nightmares are usually easily and immediately recalled on wakening. Aggression is common in dreams ${ }^{6}$ (occurring in over half the dreams in one American study) but cannot be acted out because the body is paralysed during REM sleep. During the waking stages of a dream movements may occur, but clear consciousness returns too quickly for any coordinated violent act to be committed. Crimes after a nightmare are usually motivated and cannot easily be attributed to a confusional state.

Mental experiences do occur during slow wave sleep but are quite different from typical dreams. The imagery is poorly formed and non-narrative. If the sleeper is aroused, clear consciousness does not return immediately-it may take five or 10 minutes for him to become fully awake. Finally, there is poor memory or no recall, of the experience. The body is not paralysed during slow wave sleep, and it is during this phase that sleep walking, sleep talking, and night terrors occur. Sleep walking and night terrors usually occur in the deepest phase of slow wave sleep, within two hours of falling asleep.

Highly complex, coordinated movements are possible in both sleep walking and night terrors. There are reports of sleep walkers firing guns, driving cars, walking down fire escapes, and committing murders. Night terrors differ from sleep walking in that the dreamer shows intense emotional arousal: heart rate and respiratory rate accelerate, and there is profuse perspiration. The sleeper may scream piercingly and make physical movements, such as sitting up, or, very occasionally, assaulting a sleeping partner, or fleeing from the room. Night terrors have all the characteristics of experiences during slow wave sleep. Mental content usually consists of falling, being crushed, trapped, or abandoned, dying, choking, or being attacked, although rarely it may have a thin narrative quality. 
Night terrors occur in about $3 \%$ of children between 1 and 14 years old. They are uncommon in adults and occur only in predisposed people, who usually have a family history of sleep disorders. According to Schatzman, ${ }^{8}$ murders during night terrors are very rare indeed. Only two cases have been reported in England in the past 25 years, though there have been other reports of violent acts committed during sleep that did not result in death. ${ }^{4}$

The most recent case is that of Kemp, who killed his wife during a night terror in which he dreamed he was being chased by Japanese soldiers. ${ }^{8}$ This case is of interest because it lacks some of the usual features of a night terror. The apparent detailed recall of the dream content, with vivid imagery and a narrative, approximates much more closely to a nightmare.

Night terrors allow a defence of sane automatism, which, if successful, results in acquittal. For most other violent automatic acts carried out in an organic confusional state there is a mandatory referral to hospital, usually a secure one. This difference seems illogical and suggests that the law on automatism needs revision.

Peter Fenwick

Consultant Psychiatrist,

Institute of Psychiatry,

London SE5 8AF

1 Regina $v$ Quick (1973) Queen's Bench 910.

2 Bartholomew AA. On serious violence during sleep walking. Br f Psychiatry 1986;148:476.

3 Bartmann E. Two case reports: night terrors with sleep walking-a potentially lethal disorder. J Nerv Ment Dis 1983;171:503-5.

4 Oswald I, Evans J. Serious violence during sleep walking. Br J Psychiatry 1985;147:688-91.

5 Bonkalo A. Impulsive acts and confusional states during incomplete arousal from sleep: criminological and forensic implications. Psychiar $Q$ 1974;48:400-9.

6 Hall C, Nordby V. The individual and his dreams. New York: Signet, 1972.

7 Fisher E, Calne E, Edwards A, Davis D, Fine J. A psychophysiological study of nightmares and night terrors: III. Mental content and recall of stage 4 night terrors. $\mathcal{J}$ Nerv Ment Dis

8 Schatzman M. To sleep, perchance to kill. New Scientist 1986;110(No 1514):60-2

\section{Skimping on care of the newborn is false economy}

Despite at least five national reports in the past 15 years urging improved care for the newborn, ${ }^{1.5}$ the government has not provided the necessary resources. Much has been achieved locally, but British neonatal care remains inadequate, ${ }^{6}$ unstructured, understaffed, and underequipped. These failures have been exacerbated by the success of neonatal intensive care: in the best centres $80 \%$ of babies born at 28 weeks' gestation survive, as do half of those born at 26 weeks. But achieving such results makes heavy demands on resources, and some of the best centres are particularly hard pressed because of the consequences of the Resource Allocation Working Party formula.

In 1971 the Sheldon Committee recommended that there should be one neonatal intensive care cot for every 2000 annual births and three nurses for each cot. ${ }^{1}$ By 1980 this requirement had still not been met. ${ }^{3}$ Meanwhile, the Sheldon recommendations had become outdated, and in 1981 the British Paediatric Association and the Royal College of Obstetricians and Gynaecologists emphasised the need for one intensive care cot for every 1000 births and four nurses for each cot. ${ }^{7}$ In 1984 the House of Commons Social Services Committee identified the inadequacies in neonatal intensive care and the shortage of nurses as the most urgent priority in neonatal care. ${ }^{4}$ The National Birthday Trust Fund found in 1984 that there were 641 designated neonatal intensive care cots in the United Kingdom 8 suggested by the British Paediatric Association and the Royal College of Obstetricians and Gynaecologists. In fact, only 473 of these cots were equipped and staffed for intensive care, resulting in a $35 \%$ underprovision.

The chronic shortage of nurses results partly from the continued use of the outdated Sheldon formula and partly from lack of funds and is further exacerbated by increasing difficulty in recruitment. Inadequate pay is one reason for recruitment difficulties, but another is the stress caused by staff shortages: a vicious circle has been establishedoverwork, stress, resignation, and more work for the remaining staff.

Paediatricians have been doing their best to persuade management of the need for more resources for some years, ${ }^{9-11}$ but the task is not easy in the present climate. To support their case the British Paediatric Association and British Association for Perinatal Paediatrics recently published categories of newborn care. ${ }^{12}$ Three categories have been defined: routine, special, and intensive. Each is described in detail with guidelines on how each infant should be graded. Units have been recommended to audit their workload daily or twice daily (to include the night shift). Workload can thus be related to available staffing and facilities. Early experience with the audit in Bristol has already shown that the recommendations of one intensive care cot for every 1000 births may be too low; the true requirement seems to be 1.4 cots.

Managers do not seem to accept that inadequate provision of neonatal intensive care is false economy. Neonatal intensive care is cheaper than is popularly thought ${ }^{13-15}$ and is only a small fraction of the cost of the lifelong care of individuals with avoidable handicaps." neonatal intensive care seems to reduce not only mortality but also long term morbidity.

The Maternity Services Advisory Committee Report recognised the present deficiences in newborn care but then went on to ask regions to plan improvements over the next 10 years. ${ }^{16} \mathrm{~A}$ junior health minister called this a major step forward, but the Spastics Society called it a 10 year set back. ${ }^{17}$ Paediatricians think that at most there should be two years for planning and three for implementation..$^{18}$ For too long procrastination has been the order of the day.

BRIAN D SPEIDEL

Consultant Paediatrician,

Southmead General Hospital,

Bristol BS10 5NB

1 Department of Health and Social Security Expert Group on Special Care for Babies. Repon. London: HMSO, 1971. (Chairman Sir W Sheldon.) (Report on Public Health and Medical Subjects, No 127.)

2 British Paediatric Association/Royal College of Obstetricians and Gynaecologists Liaison Committee. Recommendations for the improvement of infant care during the perinatal period in the UK. London: British Paediatric Association/Royal College of Obstetricians and Gynaecologists, 1978.

3 Social Services Committee. Second report 1979-80. Perinatal and neonatal monality. London: HMSO, 1980. (Chairman Mrs Renée Short.)

4 Social Services Committee. Third report 1983-84. Perinatal and neonatal mortality: follow up. London: HMSO, 1984. (Chairman Mrs Renée Short.)

5 British Paediatric Association. Minimum standards of neonatal care. Arch Dis Child 1983;58: 943-4.

6 Baby Life Support Systems. A survey of neonatal care in the UK. London: BLISS, 1985.

7 Standing Committee of the British Paediatric Association and Royal College of Obstetricians and Gynaecologists. Midwife and nurse training for special and intensive care of the newborm: a discussion
document. London: British Paediatric Association/Royal College of Obstetricians and Gynaecocument. Lond.

8 National Birthday Trust Fund. Survey into facilities at the place of birth. London: National Birthday Trust Fund (in press)

9 Anonymous. Falling short [Editorial]. Lancet 1984;ii:326-7.

10 Walker CHM. Special and intensive care baby units and nurse staffing in the UK. Arch Dis Child 1983;58:387-92.

11 Dunn PM. Neonatal intensive care in the United Kingdom-problems and priorities. In: Neonatal intensive care a dilemma of resources and needs. London: Spastics Society, 1984:7-12.

12 British Paediatric Association and British Association for Perinatal Paediatrics. Categories of babies requiring neonatal care. Arch Dis Child 1984;60:599-600.

13 Sandhu B, Stevenson RC, Cooke RWI, Pharoah POD. Cost of neonatal intensive care for very low birthweight babies. Lancet 1986;i:600-3. 